УДК 615.071:54.061:547.915.5:577.115.083

\title{
ИССЛЕДОВАНИЕ СЛОЖНЫХ ЭФИРОВ КАРБОНОВЫХ КИСЛОТ ИЗ НАДЗЕМНОЙ ЧАСТИ CENTAUREA SCABIOSA L.
}

\author{
() М.С. Ларькина", Т.В. Кадырова, Е.В. Ермилова \\ Сибирский государственный медицинский университет, Московский тракт, 2, \\ Томск, 634050 (Россия), e-mail:mmmaria@sibmail.com
}

Впервые из надземной части василька шероховатого (Centaurea scabiosa L.) выделены и идентифицированы с использованием ГЖХ-масс-спектрометрии сложные эфиры карбоновых кислот: этиловые эфиры пальмитиновой и олеиновой кислот (этилпальмитат, этилолеат) и дипальмитин (1,2-дипальмитоилглицерин), ранее не описанные для данного вида.

Ключевые слова: сложные эфиры карбоновых кислот, этиловый эфир пальмитиновой кислоты, этиловый эфир олеиновой кислоты, дипальмитин, Centaurea scabiosa L.

Работа поддержана грантом ФЦП (ГК 11.519.11.5010, заявка 2011-1.9-519-024-070)

\section{Введение}

Данная работа посвящена продолжению изучения Centaurea scabiosa L. сем. Astereceae, насчитывающего свыше 800 видов, из которых одним из наиболее крупных родов этого семейства является род Centaurea. Интерес к изучению видов этого рода в некоторых странах мира обусловлен богатым химическим составом и высокими фармакологической и биологической активностями $[1,2]$.

В ранее проведенных нами исследованиях выявлено, что экстракт василька шероховатого (Centaurea scabiosa L.) (ВШ), полученный на 70\% этаноле, проявляет высокие гепатопротекторные и антиоксидантные активности [3-6]. Химическое изучение данного экстракта (согласно литературным данным [1, 7-12] и собственным исследованиям [13-15]) показало, что в экстракте содержатся фенольные соединения: фенолокислоты (кофейная, коричная, феруловая, п-кумаровая, хлорогеновая, галловая и салициловая кислоты), кумарины (скополетин и умбеллиферон), флавоноиды (скутелляреин, глюкуронид скутелляреина, апиин, байкалеин и хризин) и дубильные вещества, а также сесквитерпеновые лактоны (гроссгемин, цинаропикрин) и сахара (в гидролизате фракций - глюкоза, арабиноза, рамноза, глюкуроновая и галактуроновая кислоты) и отсутствуют иридоиды, экдистероиды и сердечные гликозиды.

Однако сведения о качественном составе изучаемого экстракта неполные. Поэтому целью исследования является выделение веществ и их идентификация из экстракта надземной части василька шероховатого.

\section{Экспериментальная часть}

Надземная часть василька шероховатого была собрана в 2008 г. в окрестностях д. Новая Балахонка

Ларькина Мария Сергеевна - старший преподаватель кафедры фармацевтической химии, кандидат фармацевтических наук, e-mail: mmmaria@sibmail.com Кадырова Татьяна Владимировна - доцент кафедры фармацевтической химии, кандидат фармацевтических наук, e-mail: mmmaria@sibmail.com Ермилова Елена Васильевна - заведующая кафедрой фармацевтической химии, доктор фармацевтических наук
Кемеровской области в фазе массового цветения. Для изучения химического состава был получен экстракт на $70 \%$ этаноле методом мацерации при нагревании. С этой целью навеску (1,6 кг) сырья заливали растворителем в соотношении $1: 10$ и нагревали на водяной бане с обратным холодильником при температуре кипения растворителя в течение 1 ч. Экстракцию

\footnotetext{
* Автор, с которым следует вести переписку.
} 
проводили еще дважды. Полученное извлечение отделяли от обработанного сырья процеживанием через несколько слоев марли, растворитель удаляли под вакуумом, остаток высушивали, высушенный экстракт измельчали, выход экстрактивных веществ составил 401,5 г (25,1\%). Для разделения сложных смесей веществ полученного экстракта применяли методы избирательной экстракции, используя в качестве экстрагентов хлороформ, этилацетат и $\boldsymbol{\mu}$-бутанол.

Выделение индивидуальных соединений из этилацетатной фракции проводили методом адсорбционной колоночной хроматографии на силикагеле. Этилацетатную фракцию около 8,0 г (полученную при обработке 401,5 г экстракта) помещали на колонку с силикагелем (L 40/100), соотношение сорбент - вещество 25 : 1, высота колонки - 95 см, диаметр - 3 см, высота слоя сорбента - 40 см, высота слоя сорбента с фракцией -2 см. Элюирование проводили хлороформом, смесью хлороформ-этилацетат, постепенно повышая градиент последнего, затем этилацетатом, смесью этилацетат-этанол, этанолом.

Контроль за элюированием веществ осуществляли с помощью метода ТСХ («Сорбфил», элюенты: метанол - хлороформ $(1: 1,1: 4,1: 9))$, просматривая хроматограммы в фильтрованном УФ-свете (254 нм) до и после обработки различными реактивами: пары аммиака, $5 \%$ этанольный раствор калия гидроксида, $2 \%$ этанольный раствор алюминия хлорида, раствор диазотированной сульфаниловой кислоты и $50 \%$ серная кислота.

Для изучения компонентного состава и химического строения образцы веществ с колонки анализировали методом ГЖХ-масс-спектрометрии. Хроматограммы и масс-спектры снимали на приборе хромато-массспектрометре Finnigan Trace DSQ (США) с использованием колонки TR5MS, тип фазы 5\% фенилполифилфенилен-силоксан, длиной 30 м, диаметром 0,53 мм/мкм, в качестве газа-носителя использовали гелий, растворитель хлороформ; Т термостата - от 30 до $350{ }^{\circ} \mathrm{C}$; скорость нагрева - 10 \%мин; сканирование - 33-650 а.е.м.

\section{Обсуждение результатов}

В ходе разделения этилацетатной фракции при элюировании хлороформом была получена фракция $(0,6830$ г), содержащая смесь веществ, легко растворимая в липофильных органических растворителях, что свидетельствует о выраженном липофильном характере веществ. Выделенная фракция представляет собой прозрачную маслянистую вязкую жидкость с желтоватым оттенком и специфическим запахом, оставляющую жирное пятно на бумаге. На основании отрицательных реакций с хлоридом алюминия, диазотированной сульфаниловой кислотой, отсутствием выраженных максимумов поглощения в УФ-спектре фракция не содержит фенольные соединения. Учитывая физико-химические свойства, а также положительную реакцию на сложноэфирную связь (гидроксамовую пробу), фракция, по-видимому, содержит сложные эфиры карбоновых кислот.

Для дальнейшего разделения и установления структуры веществ фракцию анализировали на приборе хромато-масс-спектрометр Finnigan Trace DSQ (США). Хроматограмма фракции свидетельствует о наличии в ней трех основных соединений: 1 (время удерживания - 26,21 мин), 2 (время удерживания 29,27 мин) и 3 (время удерживания - 29,72 мин) (рис. 1).

Соединение 1. Согласно данным масс-спектра (рис. 2) молекулярная масса соединения равна 284 а.е.м. ([M] $\left.]^{+} 284\left(\mathrm{C}_{18} \mathrm{H}_{36} \mathrm{O}_{2}\right)\right)$. В масс-спектре присутствуют пики осколочных ионов, характерные для неразветвленной углеводородной цепи (m/z (I, \%) 43 (37), 55 (23), 57 (15), 88 (100), 143 (3), 157 (12), 239 (7)) и эфиров одноосновных карбоновых кислот с алифатическими заместителями (m/z (I, \%) 73 (15) и 101 (55)). Таким образом, согласно данным масс-спектрометрии, соединение 1 относится к алифатическим сложным эфирам неразветвленного строения. Масс-спектр соединения 1 по спектрометрической базе данных Databaze/wiley7n.L совпадает со спектром этилового эфира пальмитиновой (гексадекановой) кислоты.

Соединение 2. Согласно данным масс-спектра (рис. 3) молекулярная масса соединения равна 310 а.е.м. $\left((\mathrm{M})^{+} 310\left(\mathrm{C}_{20} \mathrm{H}_{38} \mathrm{O}_{2}\right)\right)$. В масс-спектре соединения 2 обнаружены пики осколочных ионов, присутствующие в масс-спектре ВШ 1/1 (m/z (I, \%) 55 (100), 69 (56), 88 (54), 101 (35), 157 (8)), что характерно для алифатического сложного эфира неразветвленного строения, кроме того, ионы с m/z (I, \%) 83 (43) и 110 (13) соответствуют ионам алкеновой серии, обусловленной аллильным распадом, приводящим к образованию устойчивых аллильных катионов. Масс-спектр вещества по спектрометрической базе данных Databaze/ wiley7n.L совпадает со спектром этилового эфира олеиновой (октадецен-9-овой) кислоты.

Соединение 3. Данные масс-спектра вещества (рис. 4) по спектрометрической базе данных Databaze/wiley $7 \mathrm{n} . \mathrm{L}$ совпадают с данными спектра дипальмитином (1,2-дипальмитоилглицерин) (молекулярная масса -568 а.е.м.). 
Рис. 1. ГЖ хроматограмма фракции

Рис. 2. Масс-спектр соединения 1

Рис. 3. Масс-спектр соединения 2

Рис. 4. Масс-спектр соединения 3
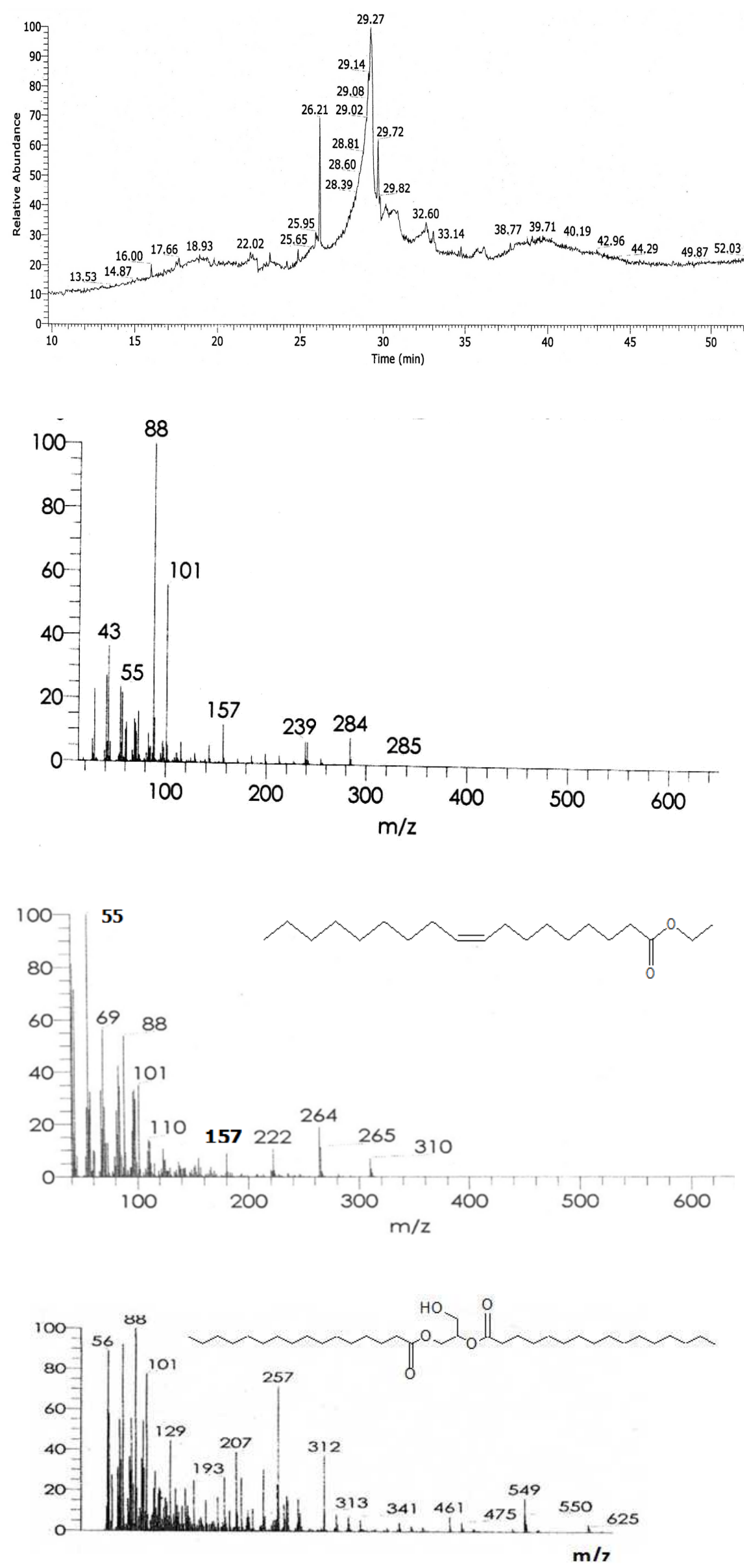


\section{Выводы}

Таким образом, впервые из василька шероховатого выделены и идентифицированы три сложных эфира карбоновых кислот.

\section{Список литературы}

1. Ларькина М.С., Кадырова Т.В., Ермилова Е.В. Фенольные соединения видов рода Centaurea мировой флоры (обзор) // Химия растительного сырья. 2011. №4. С. 7-14.

2. Khammar A., Djeddi S. Pharmacological and Biological Properties of some Centaurea Species // European Journal of Scientific Research. 2012. Vol. 84, N3. Pp. 398-416.

3. Ларькина М.С., Сапрыкина Э.В., Кадырова Т.В., Ермилова Е.В., Пешкина Р.А. Антиоксидантная активность экстракта василька шероховатого при токсическом поражении печени крыс // Вопросы биологической, медицинской и фармацевтической химии. 2011. №8. С. 25-28.

4. Ларькина М.С., Сапрыкина Э.В., Геренг Е.А., Кадырова Т.В., Ермилова Е.В., Пешкина Р.А. Гепатопротекторные свойства василька шероховатого // Вопросы биологической, медицинской и фармацевтической химии. 2011. №7. С. 28-32.

5. Кадырова Т.В., Ларькина М.С., Ермилова Е.В., Краснов Е.А., Аврамчик О.А. Антиоксидантная активность экстрактов из надземной части Centaurea scabiosa L. (Asteraceae) // Растительные ресурсы. 2010. Вып. 1. C. $102-106$.

6. Ларькина М.С., Сапрыкина Э.В., Кадырова Т.В., Ермилова Е.В. Влияние экстракта василька шероховатого на содержание общих липидов и их отдельных компонентов у крыс с гепатитом // Фармация: современное состояние и перспективы: тез. докл. междунар. науч.-практ. конф. Алматы, 2010. С. 206-207.

7. Федорова А.А. Растительные ресурсы СССР: цветковые растения, их химический состав, использование; семейства Asteraceae. Л., 1987. 326 с.

8. Немыкина Т.А., Нешта И.Д. Фитохимическое изучение васильков сибирского и шероховатого // Материалы IV Всерос. съезда фармацевтов. Воронеж, 1984. С. 446-447.

9. Кадырова Т.В., Краснов Е.А., Корнякова А.В. Противосудорожные свойства экстрактов из Centaurea scabiosa (Asteraceae) // Растительные ресурсы. 2006. №4. С. 70-75.

10. Бубенчикова В.Н. Антимикробная активность растений рода василёк // Фитонциды. Бактериальные болезни растений. Киев, 1990. Ч. 1. С. 27.

11. Бубенчикова В.Н. Фитохимическое исследование растений рода василек // Тезисы докладов 2-й республиканской конференции по медицинской ботанике. Киев, 1988. С. 205-206.

12. Vele T., Dejan D., Vlatka V. Constituents of the roots of plants species Centaurea scabiosa // J. Serb. Chem. Soc. 1994. V. 59, N12. Pp. 979-981.

13. Ларькина М.С., Кадырова Т.В., Ермилова Е.В. Изучение динамики накопления фенолкарбоновых кислот в надземной части василька шероховатого // Химия растительного сырья. 2008. №3. С. 71-74.

14. Ларькина М.С., Кадырова Т.В., Ермилова Е.В., Краснов Е.А. Количественное определение флавоноидов в надземной части василька шероховатого (Centaurea scabiosa L.) // Химико-фармацевтический журнал. 2009. №4. C. 14-17.

15. Кадырова Т.В., Ермилова Е.В., Краснов Е.А., Каминский И.П., Ларькина М.С., Дудко В.В. Химический состав перспективных растений, их антиоксидантная активность и фармакологическая активность // Новые достижения в химии и химической технологии растительного сырья: тез. докл. Всерос. науч. конф. Барнаул, 2007. C. 86 .

Поступило в редакиию 10 апреля 2012 г. 
Larkina M.S. , Kadirova T.V., Ermilova E.V. INVESTIGATION OF THE AMOUNT OF CARBOXYLIC ACID ESTERS FROM THE AERIAL PART OF CENTAUREA SCABIOSA

Syberian state medical university, Moskovskii trakt, 2, Tomsk (Russia), e-mail: mmmaria@sibmail.com

For the first time from the aerial parts of the rough cornflower (Centaurea scabiosa L.) isolated and identified using GC-mass spectrometry of carboxylic acid esters: ethyl esters of palmitic and octadecenoic acids and palmitin (1 - (hydroxymethyl) -1,2-hexadecanoic acid ester etandiolovy), not previously described for this species. scabiosa L.

Keywords: esters of carboxylic acid, ethyl ester of palmitic acid, ethyl ester of octadecenoic acid palmitin, Centaurea

\section{References}

1. Lar'kina M.S., Kadyrova T.V., Ermilova E.V. Khimiia rastitel'nogo syr'ia, 2011, no. 4, pp. 7-14. (in Russ.).

2. Khammar A., Djeddi S. European Journal of Scientific Research, 2012, vol. 84, no. 3, pp. 398-416.

3. Lar'kina M.S., Saprykina E.V., Kadyrova T.V., Ermilova E.V., Peshkina R.A. Voprosy biologicheskoi, meditsinskoi $i$ farmatsevticheskoi khimii, 2011, no. 8, pp. 25-28. (in Russ.).

4. Lar'kina M.S., Saprykina E.V., Gereng E.A., Kadyrova T.V., Ermilova E.V., Peshkina R.A. Voprosy biologicheskoi, meditsinskoi i farmatsevticheskoi khimii, 2011, no. 7, pp. 28-32. (in Russ.).

5. Kadyrova T.V., Lar'kina M.S., Ermilova E.V., Krasnov E.A., Avramchik O.A. Rastitel'nye resursy, 2010, no. 1, pp. 102-106. (in Russ.).

6. Lar'kina M.S., Saprykina E.V., Kadyrova T.V., Ermilova E.V. Farmatsiia: sovremennoe sostoianie i perspektivy: tez. dokl. mezhdunarodn. nauchno-prakt. konf. [Pharmacy: current status and prospects: Proceedings of International Scientific Conference]. Almaty, 2010, pp. 206-207. (in Russ.).

7. Fedorova A.A. Rastitel'nye resursy SSSR: tsvetkovye rasteniia, ikh khimicheskii sostav, ispol'zovanie; semeistva Asteraceae. [Plant Resources of the USSR: the flowering plants, their chemical composition, the use, of the family Asteraceae]. Leningrad, 1987, 326 p. (in Russ.).

8. Nemykina T.A., Neshta I.D. Materialy 4 Vserossiiskogo s"ezda farmatsevtov. [4 Materials of All-Russian Congress of Pharmacists]. Voronezh, 1984, pp. 446-447.

9. Kadyrova T.V., Krasnov E.A., Korniakova A.V. Rastitel'nye resursy, 2006, no. 4, pp. 70-75. (in Russ.).

10. Bubenchikova V.N. Fitontsidy. Bakterial'nye bolezni rastenii. [Volatile. Bacterial diseases of plants]. Kiev, 1990, part 1, pp. 27. (in Russ.).

11. Bubenchikova V.N. Tezisy dokladov 2-i respublikanskoi konferentsii po meditsinskoi botanike. [Abstracts of the 2nd National Conference on medical botany.]. Kiev, 1988, pp. 205-206. (in Russ.).

12. Vele T., Dejan D., Vlatka V. J. Serb. Chem. Soc., 1994, vol. 59, no. 12, pp. 979-981.

13. Lar'kina M.S., Kadyrova T.V., Ermilova E.V. Khimiia rastitel'nogo syr'ia, 2008, no. 3, pp. 71-74. (in Russ.).

14. Lar'kina M.S., Kadyrova T.V., Ermilova E.V., Krasnov E.A. Khimiko-farmatsevticheskii zhurnal, 2009, no. 4, pp. 14-17. (in Russ.).

15. Kadyrova T.V., Ermilova E.V., Krasnov E.A., Kaminskii I.P., Lar'kina M.S., Dudko V.V. Novye dostizheniia v khimii i khimicheskoi tekhnologii rastitel'nogo syr'ia: tez. dokladov vseros. nauch. konf. [New advances in chemistry and chemical engineering plant materials: Abstracts of the Scientific Conference]. Barnaul, 2007, p. 86. (in Russ.).

Received April 10, 2012

Revised December 25, 2012

\footnotetext{
* Corresponding author.
} 
